\title{
Induction of tooth and eye by transplantation of activin A- treated, undifferentiated presumptive ectodermal Xenopus cells into the abdomen
}

\author{
YASUFUMI MYOISHI ${ }^{1, \#, ~ M I H O ~ F U R U E ~}{ }^{2, \#,}$, YASUTO FUKUI ${ }^{1}$, TETSUJI OKAMOTO ${ }^{1}$ and MAKOTO ASASHIMA ${ }^{*, 3,4}$ \\ ${ }^{1}$ Department of Molecular Oral Medicine and Maxillofacial Surgery, Division of Frontier Medical Science, Graduate School of Biomedical \\ Sciences, Hiroshima University, Hiroshima, Japan, ${ }^{2}$ Department of Biochemistry and Molecular Biology, Kanagawa Dental College, \\ Yokosuka, Japan, ${ }^{3}$ SORST/Japan Science and Technology Corporation and ${ }^{4}$ Department of Life Sciences (Biology), Graduate School of Arts \\ and Sciences, The University of Tokyo, Tokyo, Japan
}

\begin{abstract}
Activin A can induce the Xenopus presumptive ectoderm (animal cap) to form different types of mesoderm and endoderm at different concentrations and the animal cap treated with activin can function as an organizer during early development. The dissociated Xenopus animal cap cells treated with activin form an aggregate and it develops into various tissues in vitro. In this study, to induce jaw cartilage from undifferentiated cells effectively, we developed a culture method to manipulate body patterning in vitro, using activin $A$ and dissociated animal cap cells. An aggregate consisting only of activin A-treated dissociated cells developed into endodermal tissues. However, when activin A-treated cells were mixed with untreated cells at a ratio of 1:5, the aggregate developed cartilage with the maxillofacial regional marker genes, goosecoid, Xenopus Distal-less 4 and $X$-Hoxa2. When this aggregate was transplanted into the abdominal region of host embryos, maxillofacial structures containing cartilage and eye developed. We raised these embryos to adulthood and found that tooth germ had developed in the transplanted tissue. Here, we show the induction of jaw cartilage, tooth germ and eye structures from animal caps using activin $A$ in the aggregation culture method. This differentiation system will help to promote a better understanding of the regulating mechanisms of body patterning and tooth induction in vertebrates.
\end{abstract}

KEY WORDS: jaw, tooth, activin, amelogenin, animal cap

\section{Introduction}

Activin $A$, a member of the TGF- $\beta$ family, has been shown to be a crucial morphogen in the vertebrate body plan, as demonstrated by its potent mesoderm-inducing activity on Xenopus undifferentiated presumptive ectoderm cells (animal cap) (Asashima et al., 2000, Green 2002). Activin A induces mesoderm and endoderm from Xenopus undifferentiated presumptive ectoderm in a dosedependent manner, whereas the untreated ectoderm forms an irregular-shaped epidermis (Asashima et al., 1990, Green and Smith 1990, Jones et al., 1993, Smith et al., 1993). At low concentrations of activin A, ventral mesoderm, such as blood-like cells, coelomic epithelium and mesenchyme are induced in the explants (Miyanaga et al., 1998). At intermediate concentrations, muscle and neural tissue are induced (Tamai et al., 1999). At high concentrations, notochord, the most dorsal mesoderm is induced (Ninomiya et al., 1999). These tissues induced by activin A are indistinguishable at the histological level from those found in normal embryos (Okabayashi and Asashima 2003). Furthermore, activin $A$ can elicit gene cascades in the animal caps with a time course that mimics the sequence in normal embryonal development. When the dissociated animal cap cells are exposed to activin $\mathrm{A}$, the aggregate of the dissociated cells distinctly expresses a range of genes in a dose-dependent manner (Green et al., 1992). An activin A-loaded bead can cause waves of gene expression to spread out through a static population of undissociated blastula

Abbreviations used in this paper: AA, activin-A; FDA, fluorescein-dextranamine; ODC, ornithine decarboxylase; TGF, transforming growth factor; TRDA, texas-red-dextran-amine.

\footnotetext{
*Address correspondence to: Professor Makoto Asashima. Department of Life Sciences (Biology), Graduate School of Arts and Sciences, The University of Tokyo, 3-8-1 Komaba, Meguro-ku, Tokyo 153-8902, Japan. Fax: +81-3-5454-4330. e-mail: asashi@bio.c.u-tokyo.ac.jp
}

\# Note: These authors contributed equally to this work. 
cells (Gurdon et al., 1994). The animal cap cells can make a low to high gene response to activin concentration.

The most characteristic property of activin $A$ is the induction of organizer activity. When an activin A-treated animal cap is transplanted into the ventral side of early gastrulae, a well-organized, secondary embryo is induced (Ninomiya et al., 1998). By combining these systems, we have demonstrated a sandwiched culture method that reproduces the fundamental embryonic body in vitro (Ariizumi and Asashima 1994). Animal caps treated with activin A, were incubated (preculture) and then sandwiched between untreated two animal caps. By this sandwiched culture method, a head or trunk-tail structure was induced depending on activin $A$ concentration and the preculture period following the activin Atreatment. It is therefore theoretically possible to reproduce embryonic induction using activin $A$ and the sandwiched culture method and to generate a developing embryo from undifferentiated presumptive ectoderm in vitro.

During craniofacial development, neural crest-derived mesenchymal cells migrate to the branchial arches and contribute extensively to formation of maxillofacial structures. Tooth formation requires a serial interaction between epithelium and neural crestderived mesenchyme in jaw (Chai et al., 2000, Wilde 1955, Zeichner-David etal., 1995). We hypothesized that tooth reproduction requires jaw induction. Studies in Xenopus development have given rise to an instructive model that cell fate can be manipulated by morphogens or inducing factors and Xenopus has been used

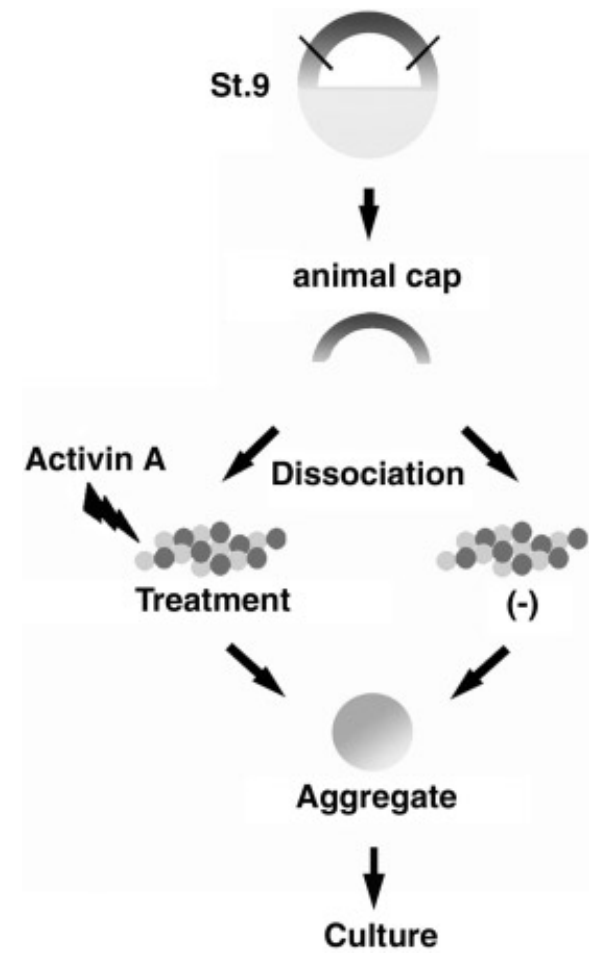

Fig. 1. Schematic diagram of the procedures involved in the aggregation culture method. Animal caps were dissected from Xenopus embryos (stage 9) and dissociated in calcium- and magnesium-free medium. The dissociated cells were incubated with or without $25 \mathrm{ng} / \mathrm{ml}$ activin A for $1 \mathrm{~h}$. After washing away free activin A five times, the activin A-treated cells were mixed with untreated cells and aggregated in calcium- and magnesium- containing medium. extensively to probe the events in early development of vertebrates (De Robertis et al., 2000, Gurdon et al., 2003, Melton 1987). Recently, we succeeded in inducing jaw cartilage from Xenopus undifferentiated presumptive ectoderm using sandwiched culture method and activin A (Furue et al., 2002). The animal cap treated with the high concentration of activin $A$, was sandwiched with untreated animal caps developed jaw cartilage with the expression of the maxillofacial regional marker genes. We hypothesized that we could induce tooth germ from animal caps using activin A. Green et al., demonstrated that the activin A-treated dissociated animal cap cells interact with untreated animal caps cells, resulting in induction of neural tissues (Green et al., 1997). We demonstrated that, when cells treated with activin $A$ were mixed with untreated cells, the activin A-treated $(1 \mathrm{ng} / \mathrm{ml})$ cells concentrated in a central mass of the aggregates and they effectively formed notochord (Kuroda et al., 2002, Kuroda et al., 1999). Therefore, we further hypothesized that it would be possible to reproduce jaw effectively in vitro using activin A and dissociated animal cap cells and jaw induction would lead to tooth formation. In this study, we have developed an aggregation culture method to manipulate the body patterning and we could induce the maxillofacial region effectively in the aggregate of the animal cap cells. When these aggregates were transplanted into the abdominal region of host embryos, maxillofacial structures containing cartilage and eye developed in the transplanted tissues. Furthermore, we raised these embryos to adulthood and found that tooth germ had developed in transplanted tissue. This aggregation culture method will promote understanding of the reproduction of body patterning and tooth induction in vertebrates.

\section{Results}

The effect of the mixture ratio of activin A-treated and untreated animal cap cells on tissue differentiation in aggregates

We dissected 12 animal caps, dissociated the animal cap cells, treated these cells with activin A and made an aggregate (Fig. 1). After 7 days in culture, we performed histological analysis with PAS/Alcian blue staining. When all of the dissociated cells of 12 animal caps were treated with $25 \mathrm{ng} / \mathrm{ml}$ of activin $\mathrm{A}$ for $1 \mathrm{~h}$ and then formed an aggregate (AA-aggregate), the aggregates developed into endodermal tissues (Fig. 2A). When dissociated cells of 6 animal caps treated with $25 \mathrm{ng} / \mathrm{ml}$ of activin A for $1 \mathrm{~h}$ were mixed with untreated dissociated cells of 6 animal caps (1:1 aggregate), the aggregates developed into mesodermal tissues, such as notochord and muscle (Fig. 2B). Finally, cartilage tissue was observed in the aggregate (Fig. 2C) when dissociated cells of 2 animal caps were treated with $25 \mathrm{ng} / \mathrm{ml}$ of activin $A$ for $1 \mathrm{~h}$ and then mixed with untreated cells of 10 animal caps (1:5 aggregate). The frequency of the aggregate that formed cartilage tissue was $67 \%$ $(20 / 30)$ of the $1: 5$ aggregates, $11 \%(5 / 42)$ of the $1: 1$ aggregates and none $(0 / 20)$ of the $A A$-aggregates. These results indicated that the ratio of mixture with activin A-treated and untreated animal cap cells reflected the induced-tissues in the aggregates and suggested that head-region was induced in 1:5 aggregate.

\section{Gene expression in the aggregates}

In order to confirm the induced-region in the aggregates, we examined gene expression of Xenopus Hoxa2 (X-Hoxa2), Xnot, 
Hoxb9, endoderminin 1d-cultured explants using RT-PCR (Fig. 2D). $X$-Hoxa2 is expressed in the 2 nd pharyngeal arch and associated with the evolution of jaws (Pasqualetti et al., 2000). The expression of Xnot, a homeobox gene is restricted to the organizer region and presumptive notochord (von Dassow etal., 1993). Hoxb9, a posterior neural marker, is expressed in the posterior part of the spinal cord (Wright et al., 1990). endodermin, a pan-endodermal marker, is localized almost exclusively to the endoderm (Sasai et al., 1996). In replicate experiments, AA-aggregates expressed endodermin at the frequency of $100 \%$ (10/10), but $X$-Hoxa2at $20 \%$ (2/10), Xnotat 10\% (1/10), Hoxb9 at $0 \%(0 / 10)$. The 1:1 aggregates expressed endodermin at $83 \%$ (10/12), Hoxb9at 92\% (11/12), XHoxa2 at 58\% (7/12) and Xnot at $92 \%(11 / 12)$. The 1:5 aggregates expressed $X$-Hoxa2at $100 \%$ (10/ $10)$, but endodermin at $30 \%,(3 /$ 10), Hoxb9at 20\% (2/10) and Xnot at $30 \%(3 / 10)$. These results revealed that endodermal tissues were induced in the AA-aggregates, trunk-tail region was induced in the 1:1 aggregates and maxillofacial region was induced in the 1:5 aggregates.

\section{Cell lineage of activin A-treated animal cap cells in the aggre- gates}

We further cultured 1:5 aggregates for 7 days (Fig. 2 E,F), or 14 days (Fig. 2G) and observed the induction of a large amount of cartilage tissue which was detected by Alcian blue staining and morphology. To follow cell lineage of activin A-treated cells in the aggregation induced cartilage, we analyzed 1:5 aggregates made of the activin A-treated cells of animal caps derived from embryos labelled with texas-red-dextranamine (TRDA) and untreated cells of animal caps derived from embryo labeled with fluorescein-dextran-amine (FDA). The Alcian bluestained cartilage was composed of TRDA-labeled-activin A-treated
A

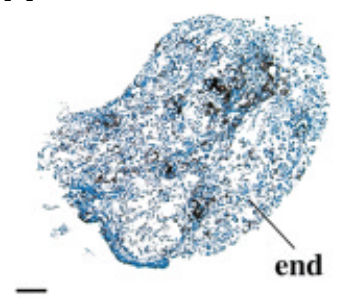

B

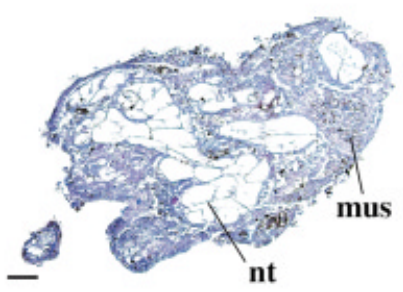

C

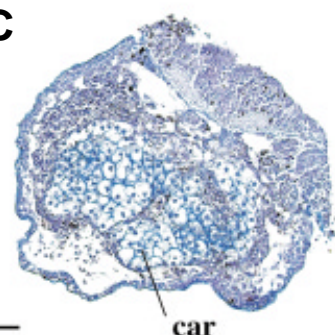

D

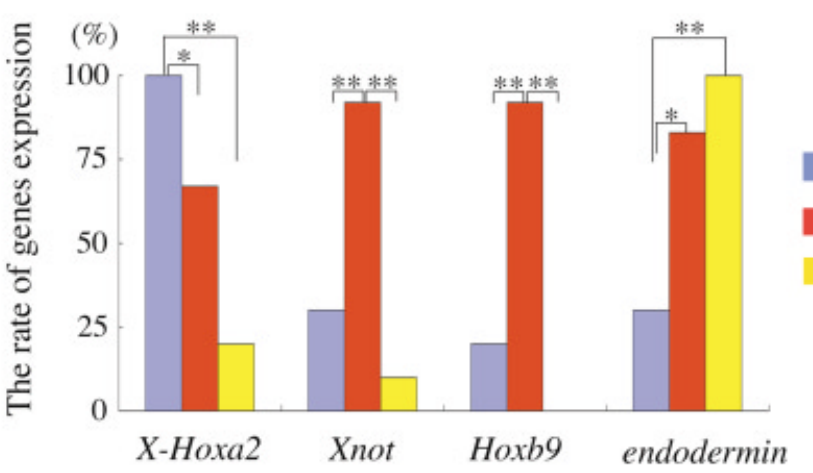

1:5 aggregate

1:1 aggregate

AA aggregate
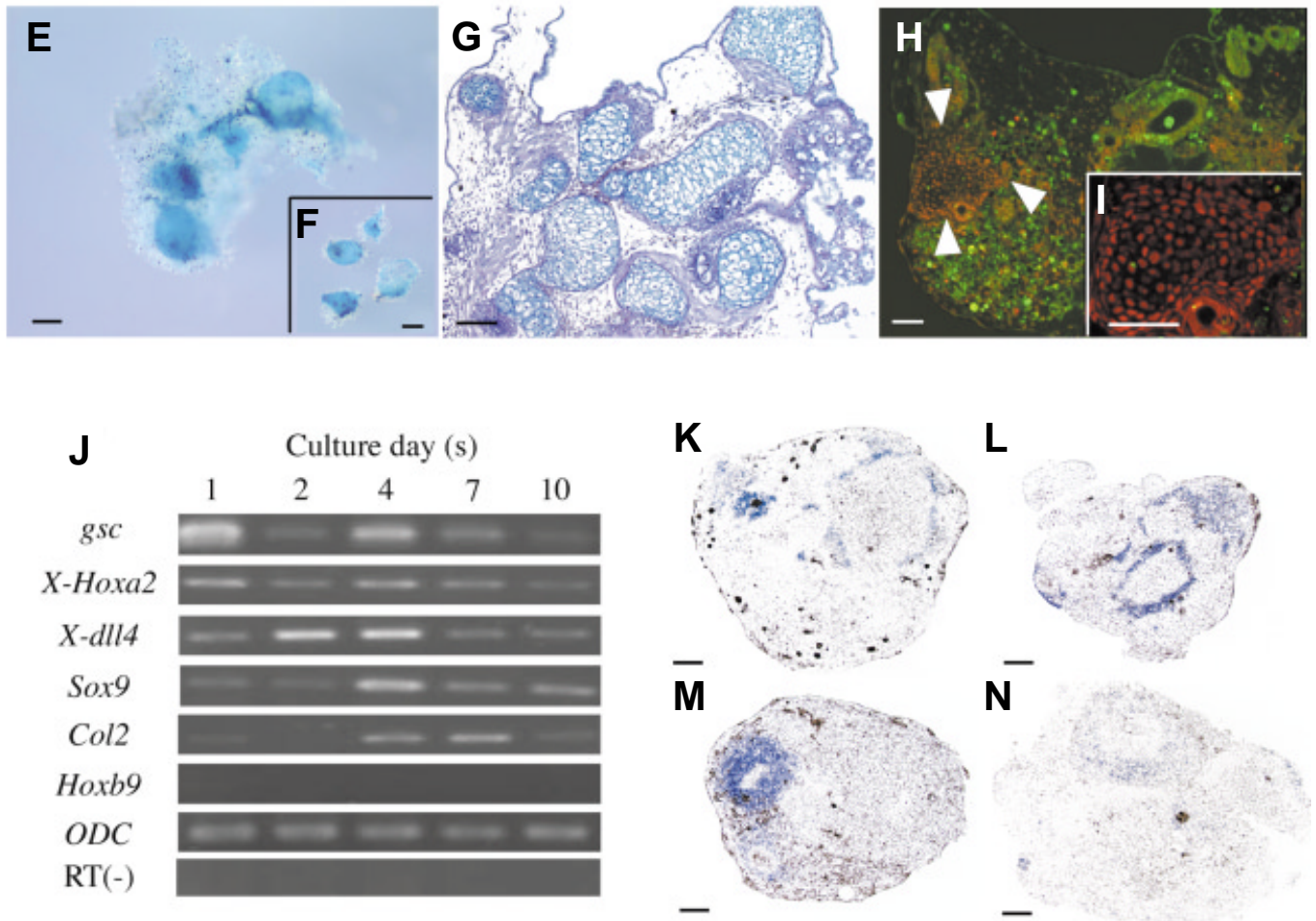

Fig. 2. The phenotypes of AA-aggregate, 1:1 aggregate and 1:5 aggregate. PAS/Alcian blue stained-sections of (A) AA-aggregate, (B) 1:1 aggregate and (C) 1:5 aggregates on culture day 7. (D) RT-PCR analysis of the genes expressed in aggregates. $\left({ }^{*} p<0.05,{ }^{*} p<0.01\right.$, AA-aggregate, $1: 5$ aggregate, $n=10 ; 1: 1$ aggregate, $\left.n=12\right)$. (E) Whole mount Alcian blue staining of the 1:5 aggregate on culture day 7. (F) Extracted cartilage tissue from (E). (G) PAS/Alcian blue stained-section of the 1:5 aggregate on culture day 14. (H) Cell-lineage analysis of the 1:5 aggregate on culture day 7. White arrowheads point to cartilage tissue. (I) Higher magnification of (H). (J) RTPCR analysis of the 1:5 aggregates following 10-day-culture. (K) X-dll4, (L) col2, (M) gsc and (N) Sox9 expression, in the 1:5 aggregates. end, endodermal tissue; car, cartilage; mus, muscle; nt, notochord. Bars, $100 \mu \mathrm{m}$. 

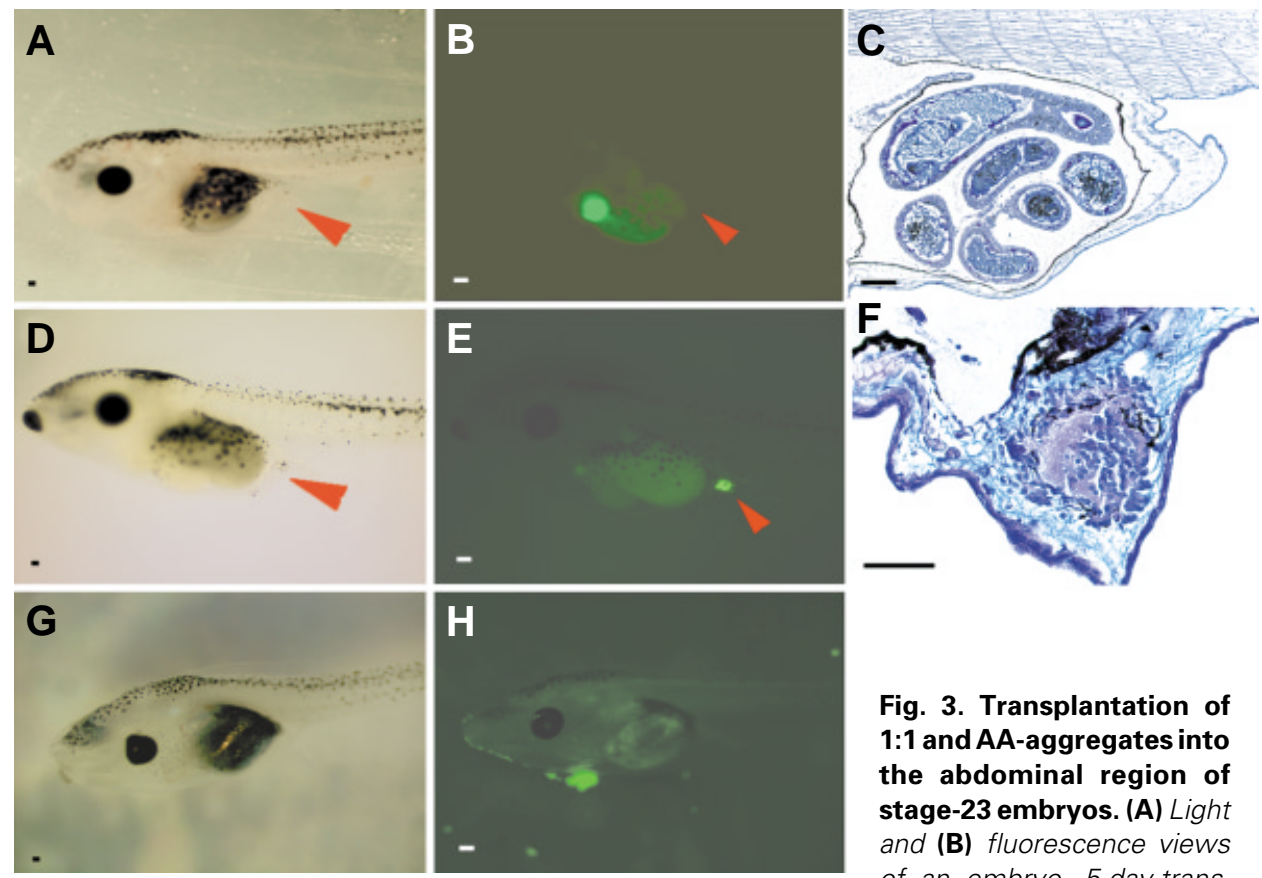

Fig. 3. Transplantation of 1:1 and $A A$-aggregates into the abdominal region of stage-23 embryos. (A) Light and (B) fluorescence views
3 A-C). When we transplanted 1:1 aggregates into the abdominal region, the transplanted tissues did not develop into cartilage (Fig. 3D-F). We transplanted 60 cases of $1: 5$ aggregates into the abdominal region. 44 cases of them were developed in the host tissues and GFP fluorescence was restricted under the abdomen region (Fig. 4A-C). PAS/Alucian blue staining of sections of the transplanted tissues showed the transplanted tissue developed into muscle, cartilage, neural and eye tissues, which were arranged into a maxillofaciallike-structure (Fig. 4 D,E) at 59\% (26/44) although the aggregates in vitrodeveloped into cartilage and mesenchymal tissues. Analysis using in situhybridization revealed that the expressions of $\mathrm{Col} 2$ (Fig. 4F), gsC (Fig. 4G), X-dl/4(Fig. 4H) and Sox9(Fig. 4I) were detected in the section of transplanted tissues. The expressions of gsc, X-Hoxa2, $X$-dII4, Sox9 and Col2, were detected, but Hoxb9expression was not detected in the dissected transplanted tissues by RT-PCR (Fig. 4L). Analysis using in situ hybridization showed that Pax6, a universal master control gene for eye morphogenesis (Onuma et al., 2002) was expressed in the of an embryo, 5-day-transplanted with AA aggregate. (C) A section of 10-day-transplanted tissues. (D) Light and (E) fluorescence views of an embryo, 5-day-transplanted with 1:1 aggregate. (F) A section of 10-daytransplanted tissues. (G) Light and (H) fluorescence views of a 7-day normal embryo. The fluorescence in the anterior region is the fed baits in the abdomen. Bars, $100 \mu \mathrm{m}$.

cells, but not FDA-labeled-untreated cells (Fig. $2 \mathrm{H}, \mathrm{I}$ ). These results indicate that cartilage was derived from activin A-treated cells.

\section{Maxillofacial regional marker gene expression in 1:5 aggre- gates}

To confirm whether the maxillofacial region was really induced in the 1:5 aggregates, we further examined the gene expression of goosecoid (gsc), Xenopus Distal-less 4(X-dll4), X-Hoxa2, Sox9and Collagen type 2 (Col2). gsc is a homeobox-containing gene that is expressed in the gastrula dorsal lip (Cho etal., 1991, McKendry etal., 1998), in the ventral head region (Newman et al., 1997) and then in the lower jaw cartilages (Furue et al., 2002). X-dll4, a homeobox gene, is expressed in anterior ectodermal derivatives (ventral forebrain, cranial neural crest, cement gland) (Papalopulu and Kintner 1993), then in ventral head region including maxillofacial cartilages (Furue et al., 2002). Sox9 is expressed in cranial neural crest cells and pharyngeal arches (Spokony et al., 2002). Col2 is expressed in immature chondrocytes (Bieker and Yazdani-Buicky 1992, Seufert et al., 1994) which was localized in craniofacial skeleton primordium and anterior notochord (Furue et al., 2002). Analysis using RT-PCR showed that all these gene expression were detected in the 1:5 aggregates (Fig. 2J). The sections of the 1:5 aggregates were hybridized with DIG-labeled RNA probes of $X$-dll/4, col2, gsc and Sox9. The expression of all these genes were localized in the 1:5 aggregates, but were not uniformly expressed (Fig. 2 K-N). These results indicated that 1:5 aggregates gave rise to maxillofacial derivatives.

\section{Implantation of the aggregates into the abdominal region}

When we transplanted AA-aggregates into the abdominal region, the transplanted tissues were assimilated with the host intestine (Fig. transplanted tissue (Fig. 4J) like normal eye (Fig. 4K). RT-PCR analysis showed that Pax6was expressed in aggregates in vitroand in 1-day- and 3-day-transplanted into the abdomen, but it was not detected in normal abdomen (Fig. 4M). These results indicated that the transplanted 1:5 aggregates could develop into maxillofacial structures including cartilage and eye with gene expression in abdominal region.

\section{Tooth induction from the aggregates in transplanted abdomen}

Xenopus laevis develops teeth in upper jaw in adulthood. We hypothesized that tooth germ could be developed in aggregates transplanted into the abdominal region. We transplanted 1:5 aggregates into the abdominal region of embryos and raise six of the host embryos until stage 66 when tooth germ differentiates in the upper jaw in normal Xenopus. The protruding transplanted tissue was seen in the proximal area between both legs (Fig. $5 \mathrm{~A}-\mathrm{C}$ ). The section of the transplanted tissues showed that cartilage differentiated into membranous bone and surrounding the thin membranous bone, tooth germ-like structures were observed in three of six hosts (Fig. 5 $D-F)$. We immunostained the tooth germ-like tissue with an antiamelogenin antibody. We detected amelogenin protein in tooth germ-like structures in the transplanted tissue (Fig. 5G), which resembled normal tooth germ (Fig. $5 \mathrm{H}$ ). These results indicated that tooth germ was developed from 1:5 aggregate.

\section{Discussion}

The experiment described here showed that the mixture ratio of activin A-treated and untreated animal cap cells reflects the body patterning when we reproduce the tissues using animal caps cells. As previously described (Ninomiya et al., 1999), endodermal 
tissues with endoderm gene expression were induced in the AAaggregates composing of all of the cells treated with high concentration of activin $A(25 \mathrm{ng} / \mathrm{ml})$. In the $1: 1$ aggregate of mixture of activin-treated and untreated animal cap cells at the ratio of $1: 1$, the trunk-tail region consisting of mesodermal tissues, such as notochord and muscle were induced with gene expression of endodermin, Hoxb9 and Xnot. In the 1:5 aggregate of mixture of activin Atreated and untreated animal cap cells at the ratio of $1: 5$, the maxillofacial region including cartilage tissue was induced with gene expression of $X$-Hoxa2. We previously showed the induction of jaw cartilages with gene expressions of gsc, $X$-dll4 and Col2 in vitro from the Xenopusanimal cap sheets using sandwiched culture method and activin $A$ (Furue et al., 2002). The 1:5 aggregates also expressed gsc, $X$-dll4, Sox 9 and Col2, suggesting that the maxillofacial region was effectively induced in the 1:5 aggregate. Gurdon demonstrated that activin A-loaded bead causes waves of gene expression to spread out through a static population of animal cap cells (Gurdon etal., 1999). Furthermore, Green etal., demonstrated that the activin A-induced mesoderm affects on non-induced animal caps cells resulting in inducing neural tissues and the dissociated cells treated with high concentration of activin A function as anterior positional value (Green et al., 1997). These findings proposed that the mixtures at different ratio of activin A-treated and untreated dissociated animal cap cells develop into different positional values depending on their ratio even though the aggregates contained the cells treated with the same range of activin A. Analysis of cell lineage in 1:5 aggregate revealed that the induced cartilage was derived from activin A-treated cells, but not untreated cells. When we previously tried inducing jaw cartilage in vitro from Xenopus animal cap sheet (Furue et al., 2002), cartilage was poorly induced from an animal cap sheet treated with activin $A$, but it was induced from an activin Atreated animal cap sheet sandwiched between two animal cap sheets. These findings suggested that induction of the maxillofacial region required the interaction between activin A-treated and untreated animal cap cells. It is assumed that mixing of cells with anterior positional values and untreated cells induces the wide range of genes and
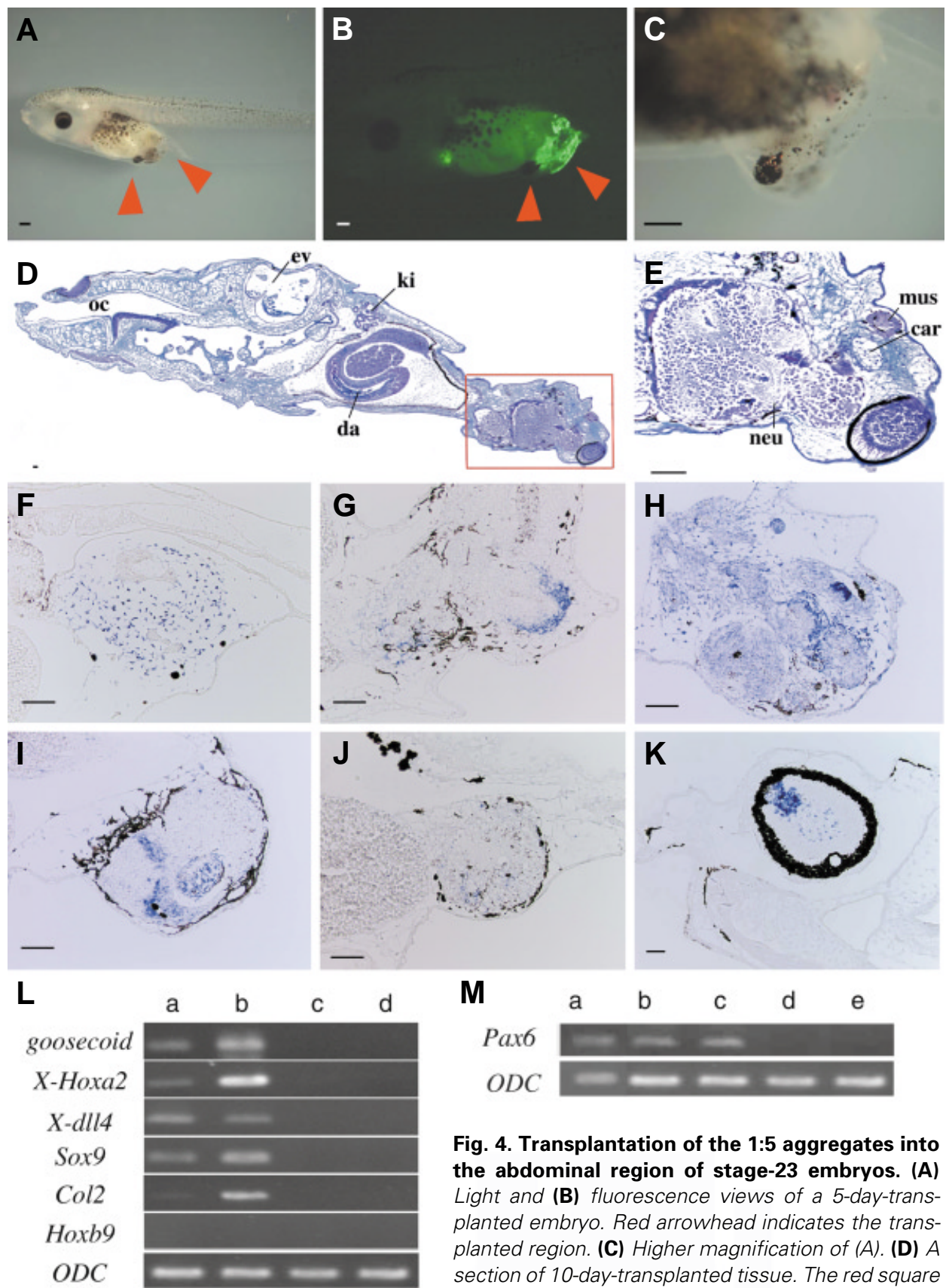

Fig. 4. Transplantation of the 1:5 aggregates into the abdominal region of stage-23 embryos. (A) Light and (B) fluorescence views of a 5-day-transplanted embryo. Red arrowhead indicates the transplanted region. (C) Higher magnification of (A). (D) A section of 10-day-transplanted tissue. The red square indicates transplanted tissue. (E) Higher magnification of (D). (F) Col2, (G) gsc, (H) X-dll4, (I) Sox9, (J) Pax6 expression in the transplanted tissue. (K) Pax6 expression in the normal eye of a stage-41 embryo. (L) RT-PCR analysis of (a) 1-day and (b) 3-daytransplanted tissue in the abdominal region and (c) 1-day-and (d) 3-day-normal abdominal tissue. (M) RTPCR analysis of Pax6 expression in (a) the aggregates on culture day 1; (b) 1-day-and (c) 3-day-transplanted tissue in the abdominal region and (d) 1-day-and (e) 3-day-normal abdominal tissue. Abbreviations: car, cartilage; ev, ear vesicle; da, digestive apparatus; ki, kidney; mus, muscle; neu, neural tissue; nt, notochord; oc, oral cavity. Bars, $100 \mu \mathrm{m}$. 

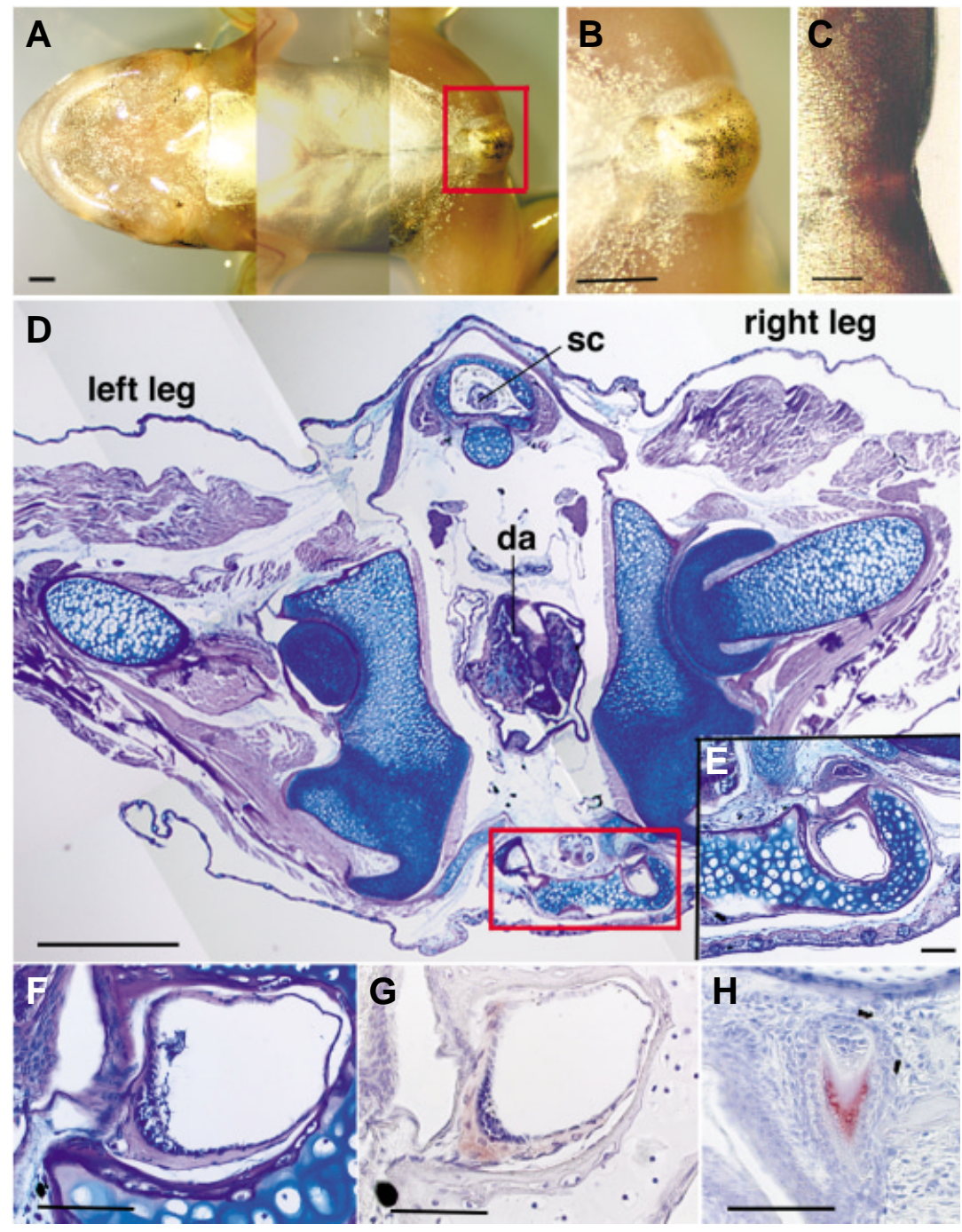

Fig. 5. Transplanted tissue in the abdominal region of grown host. (A) Ventral view of the grown host (stage 66). (B) Higher magnification of (A). (C) Normal view. (D) A section of the transplanted tissue. (E) Higher magnification and (F) tooth germ-like tissue of (D). (G) Immunolocalization of amelogenin in tooth germ-like structure in the serial section of $(F)$ and $(\mathbf{H})$ normal tooth germ in a stage-66 frog. Red squares outline the transplanted regions. Abbreviations: da, digestive apparatus; sc, spinal cord. Bars, $1 \mathrm{~mm}$ (A-D); $100 \mu \mathrm{m}(E-H)$

maxillofacial structure consisting of muscle, cartilage, neural and eye tissues was developed in the 1:5 aggregates transplanted into the abdominal region. It is well-known that Pax6 is a universal master control gene for eye morphogenesis (Onuma et al., 2002) because the ectopic expression of mouse Pax6 in Drosophila induced compound eye (Gehring 2002, Halder et al., 1995). Actually, Pax6 was expressed in the aggregates transplanted into abdomen. Pax6was expressed also in aggregates in vitroalthough eye induction was never found in the aggregate in vitro. The abdomen is a good region to culture the aggregates. These findings demonstrated that jaw cartilage induced in vitro could be developed in vivo.

We expected that the aggregates could be further cultured in the abdomen of host and develop tooth germ. We transplanted 1:5 aggregates into the abdominal region of embryos and raise the host embryos until stage 66 . We found that cartilage differentiated into membranous bone and surrounding the membranous bone, tooth germ-like structures was developed in the transplanted tissues. Amelogenin, a main component of tooth enamel matrix proteins (Fukae and Shimizu 1974, Satchell et al., 2002), is expressed in ameloblasts at highest concentration during tooth formation. Amelogenin is present in Xenopus (Toyosawa et al., 1998). We detected amelogenin protein in tooth germ-like structures in the transplanted tissue, which resembled normal tooth germ. Thus, tooth germ was developed from the 1:5 aggregates transplanted into tadpoles. Currently no master gene such as PaxG in eye development is known for tooth development. The experimental differentiation system described here may allow the discovery of such regulatory genes in tooth development. Actually, we have detected several genes related to neural crests in the 1:5 aggregates compared with the $1: 1$ aggregates. We will further investigate gene expression in the 1:5 aggregates to understand a gene cascade to tooth induction.

Deciphering how to manipulate cell differentiation during early development is essential for functional applications. The findings presented here indicated that activin $A$ regulates body patterning and cell fate and it induces a developmental cascade for maxillofacial structures including jaw and tooth. Activin A, or activin-like signal such as nodal, has been considered an important morphogen during mammalian development (Vincent et al., 2003) and in activin $\beta A$ mutant mouse embryos incisor and mandibular molar teeth fail to develop beyond the bud stage (Ferguson et al., 1998). Matzuk etal., (Matzuk etal., 1995) also reported that activin receptor II-deficient mice showed skeletal and facial abnormalities reminiscent of the PierreRobin syndrome in humans, which is characterized by brachygnathia/micrognathia. Mouse ES embryoid bodies treated with activin $A$ expressed genes found at the organizer reported in Xenopus (Johansson B.M. and M.V. 1995, Perea-Gomez etal., 2001). We believe that the differentiation system described here can be applied to mammalian ES cells. This methodology will promote an understanding of the regulating mechanisms of body patterning and tooth induction and it may aid in the development of engineered tissues for tissue replacement therapies in humans.

\section{Materials and Methods}

\section{Aggregation culture method}

Fertilized eggs were obtained from both male and female Xenopus laevis injected with $600 \mathrm{IU}$ of gonadotropin (Gestron; Denka Seiyaku Co., Kawasaski, Japan) and their jelly coat were removed with Steinberg's solution containing $4.5 \%$ cysteine hydrochloride (pH 7.8) (Ariizumi et al., 1991). Animal cap sheets cut from stage-9 Xenopus embryos were dissociated in CMF-Steinberg's solution containing $0.1 \%$ fatty acid-free bovine serum albumin (Sigma Chemical Co.). We treated the dissociated cells with $25 \mathrm{ng} / \mathrm{ml}$ activin 
A for $1 \mathrm{~h}$ and washed away activin $\mathrm{A}$. Then, we mixed and aggregated the activin A-treated dissociated cells with untreated dissociated cells at the ratio of 1:5 (1:5 aggregates) and 1:1(1:1 aggregates), or the activin A-treated cells only (AA-aggregates) and cultured in RDX medium (Fukui et al., 2003) on 96-well plates (Sumitomo Bakelite Co,. Tokyo, Japan) in a humidified atmosphere of $5 \% \mathrm{CO}_{2}$ at $20^{\circ} \mathrm{C}$.

\section{Histological examination}

The aggregates were fixed with $4 \%$ paraformaldehyde and then processed into paraffin for serial section $(6 \mu \mathrm{m})$. After deparaffinization, the sections were stained with Alcian blue and PAS and counterstained with hematoxyline for light microscopy. For whole mount Alcian blue staining, the aggregates fixed with $4 \%$ paraformaldehyde on culture day 7 were stained with Alcian blue for $16 \mathrm{~h}$ and destained in $80 \%$ methanol $/ 20 \%$ acetic acid. The epithelium of the aggregates was manually removed with fine forceps under stereoscopic microscope for light microscopy.

\section{Cell-lineage analysis in the aggregates}

Embryos at the 2-cell stage were injected with a total volume of 3 $\mathrm{nl}$ of $1 \%$ Texas Red-dextran-amine (TRDA, D-1863; Molecular Probes) or $1 \%$ fluorescein-dextran-amine (FDA, Molecular Probes) and raised up to stage-9 (Kuroda et al., 2002). The TRDA-labeled animal caps were cut, dissociated in CMF-Steinberg's solution, treated with activin $A$ and then aggregated with the untreated dissociated cells of FDA-labelled animal caps as described above. On culture day 7 , the aggregates were fixed with $4 \%$ paraformaldehyde and processed into paraffin for serial section $(6 \mu \mathrm{m})$. The deparaffinized sections were stained with Alcian blue and analyzed with fluorescence microscope and the images were captured with a charge-coupled device camera (Hammatsu Photonics, Hammatsu, Japan) and AQUAMARINE software (Hammatsu Photonics).

\section{RNA analysis}

Total RNA was extracted from the aggregates by guanidinethiocyanate-phenol-chloroform extraction method. One $\mu \mathrm{g}$ of total RNA were treated with ribonuclease (RNase)-free deoxyribonuclease (DNase) I (Invitrogen) and RNase inhibitor (TOYOBO). RTPCR was then performed according to the instruction of GIBCO RTPCR applications. Each CDNA was amplified by PCR using the following specific primer pairs: goosecoid (gsc)(Cho et al., 1991), 5'taacatttggctgccagacc -3', 5'-cttgaactgctccacaacacg-3'; X-Hoxa2 (Pasqualetti et al., 2000), 5'-gacgattaaggacagcttataccaa-3', 5'aactatagctgtctctctccagcaa-3'; Sox9 (Spokony et al., 2002), 5'cacatttggggaaaactgct-3', 5'-aaatcgcaagaaaagctgga-3'; Xnot (von Dassow etal., 1993), 5'-atacatggttggcactga-3', 5'-cttcctacagttccacatc3'; Hoxb9 (Wright et al., 1990), 5'-ctgggaccccaacattacac-3', 5'tgtttgatgagtccggtca-3'; endodermin (Sasai et al., 1996), 5'tattctgactcctgaaggtg-3', 5'-gagaactgcccatgtgcctc-3'. Primers for Pax6 (Onuma etal., 2002) and an internal control, ornithine decarboxylase (ODC) (Furue et al., 2002) were described previously. The expression rate is a percentage of the aggregation numbers in which a gene is detected divided by the experiment numbers. Significant differences were determined by Fisher's exact test.

\section{Sequences}

PCR products were inserted directly into pGEM-T vector (Promega), according to the manufacture's instructions. The inserts were sequenced by using the dye terminator-cycle sequence method with a DTCS kit (Beckman Coulter) and CEQ 2000 DNA analysis system (Beckman Coulter). The cloned PCR products were confirmed by sequence analysis as respective cDNA.

\section{In situ hybridization}

Recombinant plasmids of $X$-dll4, Col2, Sox9, gsc and Pax6were used as templates for synthesis of RNA probes. The digoxigenin (DIG)-labeled RNA sense and antisense probes were prepared from template cDNA, according to the RNA-labeling kit instructions (Roche Molecular Biochemicals). We carried out in situ hybridization on Discovery ${ }^{\mathrm{TM}}$ (Ventana Medical Systems, Inc. USA), using with DIGlabeled probes, Ribomap ${ }^{\mathrm{TM}}$ and BlueMap ${ }^{\mathrm{TM}}$ kit (Ventna).

\section{Transplantation into embryos and adults}

We made aggregates from GFP-transgenic Xenopusembryos as described above. We transplanted the 1:5 aggregates cultured for 24 $\mathrm{h}$ into the abdominal region of stage-23 embryos. The tissues were fixed with $4 \%$ paraformaldehyde, then processed into paraffin for serial section $(6 \mu \mathrm{m})$. The sections were stained with Alcian blue and PAS and counterstained with hematoxyline for light microscopy.

\section{Immunolocalization of amelogenin}

The serial section were immunostained with an anti-amelogenin rabbit polyclonal antibody (Uchida et al., 1991), visualized with peroxidase-conjugated Simple Stain MAX PO goat anti-rabbit IgG (Nichirei) and 3-amino-9-ethylcarbazol (AEC, Nichirei). Nuclei were counterstained with hematoxylin.

\section{Acknowledgments}

We are indebted to Dr. Y. Eto (Central Research Laboratory, Ajinomoto Co., Japan) for the gift of activin A. We also thank Dr. T. Uchida (Hiroshima University, Japan) for the gift of anti-amelogenin antibody. This work was supported in part by grants-in-aid for Scientific Research from the Ministry of Education, Culture, Sports, Science and Technology of Japan, ICORP and the SORST Project of the Japan Science and Technology Corporation.

\section{References}

ARIIZUMI, T. and M. ASASHIMA. (1994). In vitro control of the embryonic form of Xenopus laevis by activin A: Time and dose-dependent inducing properties of activin A-treated ectoderm. Develop. Growth Differ. 36: 499-507.

ARIIZUMI, T., N. MORIYA, H. UCHIYAMA and M. ASASHIMA. (1991). Concentration dependent inducing activity of activin A. Roux's Arch. Dev. Biol. 200: 230233

ASASHIMA, M., T. ARIIZUMI and G. M. MALACINSKI. (2000). In vitro control of organogenesis and body patterning by activin during early amphibian development. Comp Biochem Physiol B Biochem Mol Biol126: 169-78.

ASASHIMA, M., H. NAKANO, K. SHIMADA, K. KINOSHITA, K. ISHII, H. SHIBAI and N. UENO. (1990). Mesodermal induction in early amphibian embryos by activin (erythroid differentiation factor). Roux's arch Dev Bio/198: 330-335.

BIEKER, J. J. and M. YAZDANI-BUICKY. (1992). Distribution of type II collagen mRNA in Xenopus embryos visualized by whole-mount in situ hybridization. $J$ Histochem Cytochem 40: 1117-20.

CHAI, Y., X. JIANG, Y. ITO, P. BRINGAS, JR., J. HAN, D. H. ROWITCH, P. SORIANO A. P. MCMAHON and H. M. SUCOV. (2000). Fate of the mammalian cranial neural crest during tooth and mandibular morphogenesis. Development 127: 1671-9.

CHO, K. W., B. BLUMBERG, H. STEINBEISSER and E. M. DE ROBERTIS. (1991). Molecular nature of Spemann's organizer: the role of the Xenopus homeobox gene goosecoid. Cel/67: 1111-20

DE ROBERTIS, E. M., J. LARRAIN, M. OELGESCHLAGER and O. WESSELY (2000). The establishment of Spemann's organizer and patterning of the vertebrate embryo. Nat Rev Genet 1: 171-81. 
FERGUSON, C. A., A. S. TUCKER, L. CHRISTENSEN, A. L. LAU, M. M. MATZUK and P. T. SHARPE. (1998). Activin is an essential early mesenchymal signal in tooth development that is required for patterning of the murine dentition. Genes Dev 12: 2636-49.

FUKAE, M. and M. SHIMIZU. (1974). Studies on the proteins of developing bovine enamel. Arch Oral Biol19: 381-6.

FUKUI, Y., M. FURUE, Y. MYOISHI, J. D. SATO, T. OKAMOTO and M. ASASHIMA. (2003). Nutrition supplemented medium for a long-term culture of Xenopus presumptive ectoderm. Develop. Growth Differ. 45: 499-506.

FURUE, M., Y. MYOISHI, Y. FUKUI, T. ARIIZUMI, T. OKAMOTO and M. ASASHIMA. (2002). Activin A induces craniofacial cartilage from undifferentiated Xenopus ectoderm in vitro. Proc Natl Acad Sci USA 99: 15474-9.

GEHRING, W. J. (2002). The genetic control of eye development and its implications for the evolution of the various eye-types. Int J Dev Bio/46: 65-73.

GREEN, J. (2002). Morphogen gradients, positional information and Xenopus: interplay of theory and experiment. Dev Dyn 225: 392-408.

GREEN, J. B., T. L. COOK, J. C. SMITH and R. M. GRAINGER. (1997). Anteroposterior neural tissue specification by activin-induced mesoderm. ProcNat/Acad SCl USA 94: 8596-601.

GREEN, J. B., H. V. NEW and J. C. SMITH. (1992). Responses of embryonic Xenopus cells to activin and FGF are separated by multiple dose thresholds and correspond to distinct axes of the mesoderm. Cel/71: 731-9.

GREEN, J. B. and J. C. SMITH. (1990). Graded changes in dose of a Xenopus activin A homologue elicit stepwise transitions in embryonic cell fate. Nature 347: 391-4.

GURDON, J. B., J. A. BYRNE and S. SIMONSSON. (2003). Nuclear reprogramming and stem cell creation. Proc Natl Acad Sci USA 100 Suppl 1: 11819-22.

GURDON, J. B., P. HARGER, A. MITCHELL and P. LEMAIRE. (1994). Activin signalling and response to a morphogen gradient. Nature 371: 487-92.

GURDON, J. B., H. STANDLEY, S. DYSON, K. BUTLER, T. LANGON, K. RYAN, F. STENNARD, K. SHIMIZU and A. ZORN. (1999). Single cells can sense their position in a morphogen gradient. Development 126: 5309-17.

HALDER, G., P. CALLAERTS and W. J. GEHRING. (1995). Induction of ectopic eyes by targeted expression of the eyeless gene in Drosophila. Science 267: 1788-92.

JOHANSSON B.M. and W. M.V. (1995). Evidence for involvement of activin A and bone morphogenetic protein 4 in mammalian mesoderm and hematopoietic development. Mol. Cell. Biol. 15,: 141-151.

JONES, E. A., M. H. ABEL and H. R. WOODLAND. (1993). The possible role of mesodermal growth factors in the formation of endoderm in Xenopus laevis. Roux's Arch. Dev. Biol. 202: 233-239.

KURODA, H., M. INUI, K. SUGIMOTO, T. HAYATA and M. ASASHIMA. (2002). Axia protocadherin is a mediator of prenotochord cell sorting in Xenopus. Dev Bio/244: 267-77.

KURODA, H., H. SAKUMOTO, K. KINOSHITA and M. ASASHIMA. (1999). Changes in the adhesive properties of dissociated and reaggregated Xenopus laevis embryo cells. Dev Growth Differ 41: 283-91.

MATZUK, M. M., T. R. KUMAR, A. VASSALLI, J. R. BICKENBACH, D. R. ROOP, R. JAENISCH and A. BRADLEY. (1995). Functional analysis of activins during mammalian development. Nature 374: 354-6.

MCKENDRY, R., R. M. HARLAND and S. E. STACHEL. (1998). Activin-induced factors maintain goosecoid transcription through a paired homeodomain binding site. Dev Bio/204: 172-86.

MELTON, D. A. (1987). Translocation of a localized maternal mRNA to the vegetal pole of Xenopus oocytes. Nature 328: 80-2.

MIYANAGA, Y., R. SHIURBA, S. NAGATA, C. J. PFEIFFER and M. ASASHIMA. (1998). Induction of blood cells in Xenopus embryo explants. Dev Genes Evo/207: 417-26.

NEWMAN, C. S., M. W. GROW, O. CLEAVER, F. CHIA and P. KRIEG. (1997). Xbap, a vertebrate gene related to bagpipe, is expressed in developing craniofacial structures and in anterior gut muscle. Dev Bio/181: 223-33.

NINOMIYA, H., T. ARIIZUMI and M. ASASHIMA. (1998). Activin-treated ectoderm has complete organizing center activity in Cynops embryos. Dev Growth Differ40: 199-208.

NINOMIYA, H., S. TAKAHASHI, K. TANEGASHIMA, C. YOKOTA and M. ASASHIMA (1999). Endoderm differentiation and inductive effect of activin-treated ectoderm in Xenopus. Dev Growth Differ 41: 391-400.
OKABAYASHI, K. and M. ASASHIMA. (2003). Tissue generation from amphibian animal caps. Curr. Opin. Genet. Dev. 13: 502-507.

ONUMA, Y., S. TAKAHASHI, M. ASASHIMA, S. KURATA and W. J. GEHRING. (2002). Conservation of Pax 6 function and upstream activation by Notch signaling in eye development of frogs and flies. Proc Nat/ Acad Sci USA 99: 2020-5.

PAPALOPULU, N. and C. KINTNER. (1993). Xenopus Distal-less related homeobox genes are expressed in the developing forebrain and are induced by planar signals. Development 117: 961-75.

PASQUALETTI, M., M. ORI, I. NARDI and F. M. RIJLI. (2000). Ectopic Hoxa2 induction after neural crest migration results in homeosis of jaw elements in Xenopus. Development 127: 5367-78.

PEREA-GOMEZ, A., M. RHINN and S. L. ANG. (2001). Role of the anterior visceral endoderm in restricting posterior signals in the mouse embryo. Int J Dev Bio/45: 311-20.

SASAI, Y., B. LU, S. PICCOLO and E. M. DE ROBERTIS. (1996). Endoderm induction by the organizer-secreted factors chordin and noggin in Xenopus animal caps. EMBO J15: 4547-55.

SATCHELL, P. G., X. ANDERTON, O. H. RYU, X. LUAN, A. J. ORTEGA, R. OPAMEN, B. J. BERMAN, D. E. WITHERSPOON, J. L. GUTMANN, A. YAMANE, M. ZEICHNER-DAVID, J. P. SIMMER, C. F. SHULER and T. G. DIEKWISCH. (2002). Conservation and variation in enamel protein distribution during vertebrate tooth development. J Exp Zoo/294: 91-106.

SEUFERT, D. W., J. HANKEN and M. W. KLYMKOWSKY. (1994). Type II collagen distribution during cranial development in Xenopus laevis. Anat Embryol (Berl) 189: $81-9$.

SMITH, J. C., V. CUNLIFFE, J. B. GREEN and H. V. NEW. (1993). Intercellular signalling in mesoderm formation during amphibian development. Philos Trans $R$ Soc Lond B Biol Sci340: 287-96.

SPOKONY, R. F., Y. AOKI, N. SAINT-GERMAIN, E. MAGNER-FINK and J. P. SAINTJEANNET. (2002). The transcription factor Sox9 is required for cranial neural crest development in Xenopus. Development 129: 421-32.

TAMAI, K., C. YOKOTA, T. ARIIZUMI and M. ASASHIMA. (1999). Cytochalasin B inhibits morphogenetic movement and muscle differentiation of activin-treated ectoderm in Xenopus. Dev Growth Differ 41: 41-9.

TOYOSAWA, S., C. O'HUIGIN, F. FIGUEROA, H. TICHY and J. KLEIN. (1998). Identification and characterization of amelogenin genes in monotremes, reptiles and amphibians. Proc Nat/ Acad Sci USA 95: 13056-61.

UCHIDA, T., T. TANABE, M. FUKAE, M. SHIMIZU, M. YAMADA, K. MIAKE and S. KOBAYASHI. (1991). Immunochemical and immunohistochemical studies, using antisera against porcine $25 \mathrm{kDa}$ amelogenin, $89 \mathrm{kDa}$ enamelin and the $13-17 \mathrm{kDa}$ nonamelogenins, on immature enamel of the pig and rat. Histochemistry $96: 129$ 38.

VINCENT, S. D., N. R. DUNN, S. HAYASHI, D. P. NORRIS and E. J. ROBERTSON. (2003). Cell fate decisions within the mouse organizer are governed by graded Nodal signals. Genes Dev17: 1646-62.

VON DASSOW, G., J. E. SCHMIDT and D. KIMELMAN. (1993). Induction of the Xenopus organizer: expression and regulation of Xnot, a novel FGF and activinregulated homeo box gene. Genes Dev 7: 355-66.

WILDE, C. E. (1955). The urodele neuroepithelium, The differentiation in vitro of the cranial neural crest. J. Exp. Zoo/130: 573-591.

WRIGHT, C. V., E. A. MORITA, D. J. WILKIN and E. M. DE ROBERTIS. (1990). The Xenopus XIHbox 6 homeo protein, a marker of posterior neural induction, is expressed in proliferating neurons. Development 109: 225-34.

ZEICHNER-DAVID, M., T. DIEKWISCH, A. FINCHAM, E. LAU, M. MACDOUGALL, J. MORADIAN-OLDAK, J. SIMMER, M. SNEAD and H. C. SLAVKIN. (1995). Control of ameloblast differentiation. Int J Dev Bio/39: 69-92.
Received: June 2004

Reviewed by Referees: August 2004

Modified by Authors and Accepted for Publication: September 2004 Edited by: Makoto Asashima 